\title{
Strategic Planning Assessment of Tertiary Institutions in Kano State, Nigeria
}

\section{BABALOLA Victor Tubosun}

\author{
Faculty of Education, Yusuf Maitama \\ Sule University, Kano, Nigeria. \\ Email:10lababa85@ymail.com \\ Licensed: \\ This work is licensed under a Creative \\ Commons Attribution 4.0 License.
}

Keywords:

Educational planning

Strategic planning

Strategic planning process

Tertiary institutions

Kano State.

Accepted: 30 September 2019

Published: 11 October 2019

\begin{abstract}
This article looks into the strategic planning assessment of tertiary institutions in Kano State. Adopting a descriptive survey design, all lecturers and non-academic staffs at the management positions in the selected tertiary institutions constitutes the study population. Two hundred and ninety five (295) individuals were sampled with stratified random sampling techniques based on the recommendation of (Research Advisors, 2006). Questionnaires on Strategic Planning Assessment of Tertiary Institutions (QSPATI)" was used to collect data for the study. QSPATI was subjected to validities of two experts from Bayero University (BUK) and Tusuf Maitama Sule University, Kano (YUMSUK) respectively. To ascertain the reliability of the QSPATI, a pilot study was conducted on 10\% of the staff of YUMSUK and 0.82 Kuder Richardson formula 21 reliability coefficient ( $r$ ) was obtained. Descriptive statistics was used to analyze the data where the research questions were answered with mean and standard deviation. The hypotheses were tested with Kyle square at 0.05-level of significance. It was discovered that not all tertiary institution in Kano State has a popular Strategic Planning Unit (SPU) while others has misplace priorities in their plans. The study concludes that the failure of tertiary institution in Kano State to be among the best ranked institutions in the world has to do with misplaced priorities in the available strategic plans. It is recommends that these tertiary institutions should engage in efficient and effective strategic planning for maximum productivity and competitive advantage.
\end{abstract}

Funding: This study receive no specific financial support.

Competing Interests: The author declares that there are no conflicts of interests regarding the publication of this paper.

\section{Introduction}

Tertiary institutions in Nigeria are post-secondary institutions such as Universities, Colleges of Education, Monotechnics, Polytechnics, Innovative Enterprise Institutions (IEIs), and Specialized Institutions such as Colleges of Agriculture, School of Health and Technology and the National Teachers' Institutes (Federal Republic of Nigeria, 2013). By this, one may conclude that tertiary institutions provide opportunities for secondary school holders to further their studies for higher qualifications and Degrees.

Apart from the primary goal of these institutions in contributing to national development through the production of qualitative manpower, they are as well expected to provide accessible and affordable learning opportunities to their varieties of clients. While forging and cementing national unity, they should promote national and international understanding and interaction. By using the available resources within their reach, they should provide career counseling and cultivate the culture of life-long learning and self reliance in students through entrepreneurship skills. This among others will go a long way to reduce unemployment issues which has characterized Nigerian economy.

It is obvious that these responsibilities cannot be realized if not through qualitative enrollment process, effective teaching and learning, good research, juicy staff welfare packages and high standard facilities. Also, the role of a practical based, functional and relevant curriculum must not be underrated. Above all, researches 
and cross-fertilization of ideas are crucial to cognitively empower students for the jet-age challenges of knowledge based economy.

Based on this premise, a tertiary institution that performed these functions at a minimum cost is said to be productive. Whereby, those that have surmounted all odds to stand tall among the best in the world in term of ranking is said to have high competitive advantage. Hence, for the purpose of productivity and competitive advantages, the major activities of every Tertiary Institution in Nigeria should be geared towards; Teaching, Research, Community services, knowledge transfer and international outlooks which are the major yardstick for global ranking.

Tertiary Institutions in Kano state consists of three federally supported institutions; Bayero University Kano (BUK) and two federal colleges of education (FCE, K and FCET, B). Similarly, there are other ten (10) State-run institutions that provide post-secondary opportunities in a variety of fields. The Ministry of Health runs four (4) institutions providing professional training for the health sector. While, the remaining six (6) tertiary institutes are being controlled by the State Ministry of Tertiary Education (SMTE) and provide courses in vocational training, teacher training, and remedial studies for secondary school leavers, Islamic studies and courses in agriculture and sciences.

Educational planning is the process of setting in advance, policies, strategies, procedures, programmes and standards through which educational goals and objectives can be achieved in the future. It is very good to note that every stage of planning require some financial implications. This is because no educational institution can survive but under a friendly economic environment. The funds needed must come either directly or indirectly from the economy. Hence, it has becomes the vogue for education planners to first address themselves to economic problems as a prelude to an in-depth analysis of educational issues. This centrality of education to the national economy makes its proper planning crucial.

Often, in every tertiary institution, there are two types of planning which includes; strategic and operational planning. Operational planning depends greatly on strategic planning at the upper management level. Operational planning itself operates at the middle and the lower management levels. Strategic planning uses strategies to achieve strategic goals while Operational plans uses tactics and activities to achieve organizational objectives. "Strategies" are general description of actions the organization often uses to achieve the Strategic goals. In other words, strategies are policies, activities, tactics and programs formulated for the purpose of achieving strategic goals. Hence, for a tertiary institution to function productively and maintain competitive advantage in this era of economic crisis, the role of strategic planning cannot be overemphasized.

Historically, the concept of strategic planning emerged in the United States in the 1960's to facilitate long-term decision-making in the private sector. It evolved into the broader concept of strategic management in the following decade and used to address the need to integrate planning with implementation. By the end of the 1970's both concepts were transferred and applied to higher education management in Europe and the United States of America, at a time when the countries had serious problems with student population, funding and increased competition between institutions (UniJos, 2015).

Nevertheless, with the failure of African Universities in the 1990's to successfully address the problems of fading quality, inadequate funding, staff and student unrest, African Ministers of Finance identified the revitalization of African Universities as a critical developmental need and solicited for World Bank support. The Bank in turn, identified constraints limiting the ability of the universities to take remedial action to include political sensitivities, financial limitations and ineffective management. The ministers then made proposals to change the course of African Universities through the development of strategic plans, increased investments to higher education by the World Bank and other donors among others.

According to Gawie and Masese (2016) strategic planning basically includes a group of instruments, operations and concepts structured to help managers, leaders and planners think and act strategically. The process usually includes a classification exercise that identifies the highest priority goals and initiatives as well as ensuring that the institutions are associated with the changing internal and external environment. However, to showcase the intrinsic qualities of strategic planning in any tertiary institution, a number of processes which must not be done haphazardly are involved. These are shown in Figure 1.

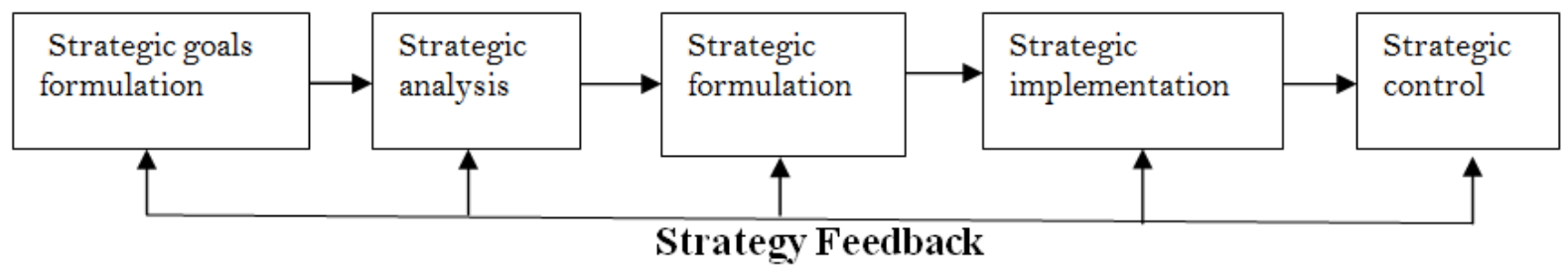

Figure-1. Strategic planning process model.

Strategic Goals are broad and general results the organization wish to achieve by the end of the period covered by the plan usually between 3-5years. Strategic analysis deals with systematic analysis of educational Strengths, Weaknesses, Opportunities and Threats (SWOT). According to Ololube (2013) Strategic formulation involves framing time-bound statements of actions and activities targeted at achieving the stated 
goals. Whereby, Strategic implementation is an act of putting into actions, the predetermined strategies, programs, tactics, policies and activities using the available resources. Finally, Strategic control has to do with supervision and evaluation of strategic planning implementation process. It also implies breaking down of strategic plan into operational plans and evaluation of individual's efforts towards realization of the strategic goals.

The purpose of Kano State's Strategic Planning for Tertiary Institutions is to assist in poverty reduction and economic developmental efforts through the enhancement of Kano State's human resources. Ultimately, the aim is to enable all citizens' access to tertiary education in order to develop them individually and improve their social and economic well-being and to play their part in the development of the State and the country at large.

At this juncture, it is good to note that the challenges which higher education institutions are facing nowadays raise the high demands to adopt a new and innovative strategic planning. This will help them cope with the challenges and to ensure their coping sustainability.

\subsection{Research Problems}

It has been noticed in the recent years that none of the Kano based tertiary institutions do feature among the best ten tertiary institutions in Africa let alone in the world. This is a big problem that this paper seeks to provide remedies with maximum vigor using strategic planning framework. These are happening perhaps Tertiary institutions in Kano State have not measured up to standard in the formulation and implementation of Strategic planning. In this vein, Chimuka (2016) states that strategic planning is a vehicle that facilitates improved performance. The origin of such performance is in the ability of strategic plans to improve the soundness of finance and budget by the innovative strategic management (Kim, 2013). Strategic planning also helps in breeding creative social elite and assists in keeping pace with global concept of higher education which promotes intake of oversea students. Also by strengthening the campus-industry network, flourishing research and cooperation it maximizes the quality life of the workers and learners.

However, apart from poor planning which usually feature in failure to prioritize strategic goals for productivity and competitive advantage, poor implementation is another area of concern which can render the whole effort useless. Kariuki, Maiyo, and Ndiku (2016) posit in this regards that learning orientation of the managers and employees whom they describe as the foot soldiers of strategic implementation is highly necessary. This learning orientation requires emphasis on openness, collaboration, equity, trust and continuous improvement.

\subsection{Research Objectives}

Based on the research problems of this study, the objectives were raised to:

1. Assess the availability of strategic planning in tertiary institutions in Kano State.

2. Investigate the prioritized strategic goals in tertiary institutions in Kano State.

3. Assess the variation in the availability of strategic plans in the tertiary institutions.

4. Assess variation in prioritized strategic goals in tertiary institutions in Kano State.

These four objectives were divided into two research questions and two research hypotheses depending on better means to achieve them as follows:

\subsection{Research Questions}

- What is the availability of strategic planning in tertiary institutions in Kano State?

- What are the prioritized strategic goals in tertiary institutions in Kano State?

\subsection{Research Hypothesis}

The null hypotheses are:

$H_{o 1}$ : There is no significant difference in the Strategic plan's availability in tertiary institutions.

$H_{o:}$ : There is no significant difference in the priorities given to strategic goals in tertiary institutions in Kano State.

\subsection{Research Methodology}

The methodology adopted in this study is descriptive survey. The population covered all tertiary institutions in Kano State. This extends to all the post secondary institutions in the State. However, the study was delimited to the Universities, polytechnics and Colleges of Education only. The institutions use and their years of establishment are as follows in Figure 2. 


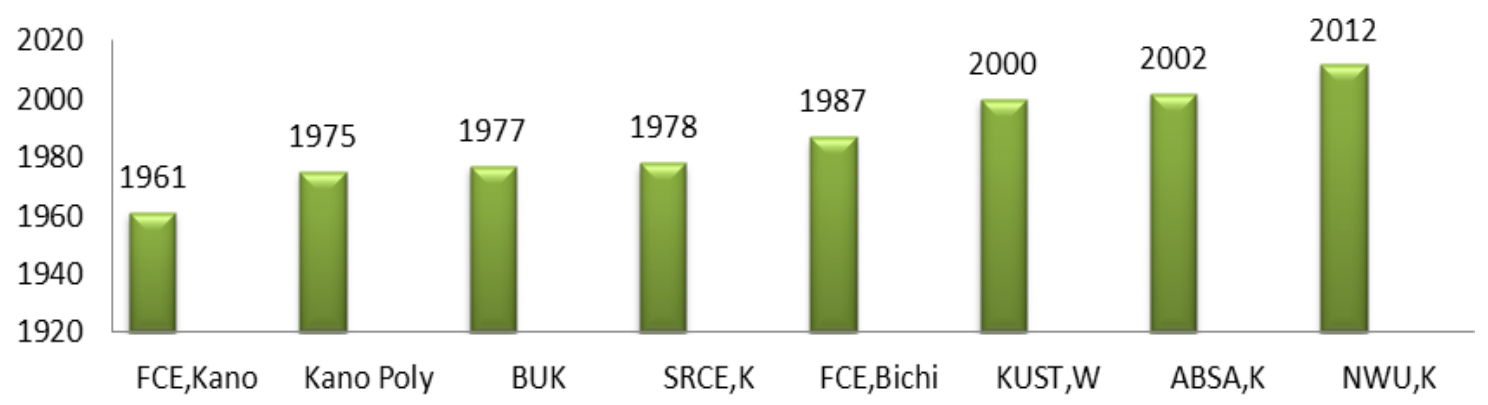

$\square$ Year Established $\square$ Column1 $\square$ Column2

Figure-2. A chart showing the growth of tertiary institutions in Kano State.

By Figure 2 the oldest Tertiary Institution is Kano State is Federal College of Education Kano (FCE, K) established in 1961 (57years Old) while the youngest is Yusuf Maitama Sule University Kano (NWU, K) which was established in 2012 (6years Old). Despite the fact that Tertiary institutions in Kano State are younger in Age compared to their counterparts that are usually rated higher in the world ranking, there is a need to prepare for the future.

The target population of the study encompasses all academic staff and non-academic personnel at the management positions of the selected institutions. From this population, two hundred and ninety five (295) respondents were selected as sample, using stratified random sampling technique in obedience to the recommendation of Research Advisors (2006).

A structured instrument called Questionnaire on Strategic Planning Assessment in Tertiary institutions (QSPATI) was used to collect data for the study. It was subjected to face, items and content validities of experts from Bayero University Kano (BUK), and Yusuf Maitama Sule University, Kano (YUMSUK) respectively. The reliability coefficient $(r)$ of the instrument was determined to be 0.82 through test-re-tests method and Kuder Richardson Formula 21. Research questions were answered using Mean(x) score where 2.50 was used as the decision cut-off point. Kyle square was used to test the hypotheses at 0.05-level of significance.

1.6. Data Presentation and Analyses

This presents the synopsis of data collected, data analysis procedures and data analyses.

Table-1. Distribution and return of questionnaires in tertiary institutions in Kano State.

\begin{tabular}{|c|c|c|c|c|c|c|}
\hline Institutions & $\begin{array}{l}\text { Institution } \\
\text { category }\end{array}$ & $\begin{array}{c}\text { Number } \\
\text { distributed }\end{array}$ & $\begin{array}{l}\text { Number } \\
\text { returned }\end{array}$ & $\begin{array}{c}\text { Number } \\
\text { not } \\
\text { returned }\end{array}$ & $\begin{array}{c}\% \text { of } \\
\text { returned }\end{array}$ & $\begin{array}{l}\text { \% of not } \\
\text { returned }\end{array}$ \\
\hline $\begin{array}{l}\text { Sa'adatu Rimi } \\
\text { College of } \\
\text { Edu.,(SRCE) } \\
\end{array}$ & $\mathrm{COE}$ & 54 & 50 & $\mathrm{O4}$ & $92.6 \%$ & $7.4 \%$ \\
\hline $\begin{array}{c}\text { Kano State } \\
\text { Polytechnics, Kano } \\
(\mathrm{KSP})\end{array}$ & Poly & 105 & 100 & 05 & $95.3 \%$ & $4.7 \%$ \\
\hline $\begin{array}{c}\text { Bayero University, } \\
\text { Kano (BUK) }\end{array}$ & University & 50 & 45 & 05 & $90.0 \%$ & $10.0 \%$ \\
\hline $\begin{array}{c}\text { Northwest } \\
\text { University, Kano }\end{array}$ & University & 27 & 25 & $\mathrm{O} 2$ & $92.6 \%$ & $7.4 \%$ \\
\hline Total & Six Schools & 320 & 295 & 25 & $92.2 \%$ & $7.8 \%$ \\
\hline
\end{tabular}

The analyses in this article were based on the questionnaires administered duly completed and returned by the respondent from during the field survey. 


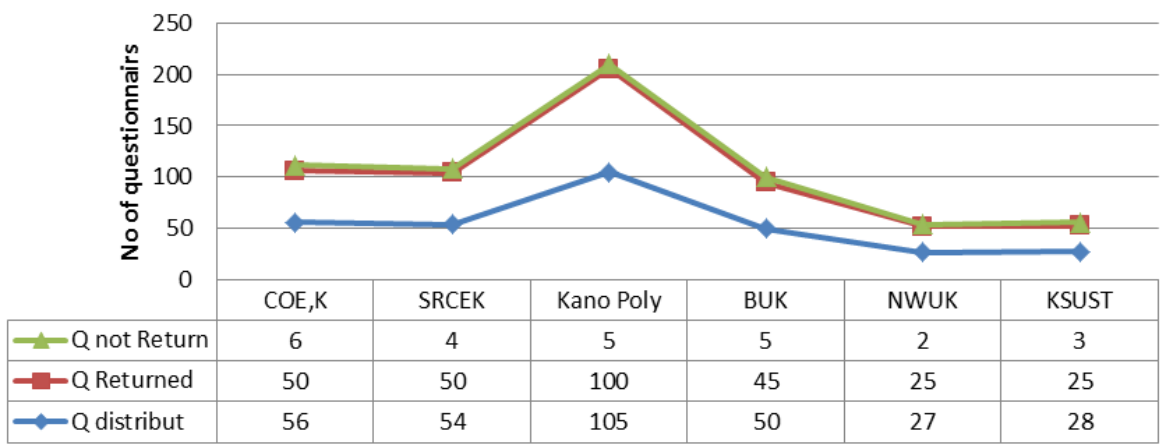

Source: Field study, (2018).

Figure-3. Chart of questionnaires distributed and returned.

\subsection{Result of Research Questions}

The data obtained from this research work was analyzed using means and standard deviation. Considering the three point rating scale used in the instrument, a decision rule was drawn where a cutoff point of 2.50 mean was considered. All items with a mean score of 2.50 and above were considered as "Agree" while the lower scores were considered as "Disagree". The research questions are answered as follows:

Table-2. The availability of Strategic planning in tertiary institutions in Kano State.

\begin{tabular}{c|l|c|c|c|c|c|c}
\hline $\mathbf{S} / \mathbf{N}$ & Items & $\mathbf{A}$ & $\mathbf{U}$ & $\mathbf{D}$ & $\mathbf{T o t a l}$ & $\mathbf{X}$ & Remark \\
\hline 1. & $\begin{array}{l}\text { Your institution has a strategic plan that } \\
\text { guide its activities. }\end{array}$ & 191 & 36 & 68 & 295 & 2.42 & Disagree \\
\hline 2. & $\begin{array}{l}\text { Your institution needs strategic plan to } \\
\text { find solutions to its challenges and achieve } \\
\text { goals. }\end{array}$ & 230 & 35 & 30 & 295 & 2.68 & Agree \\
\hline 3. & $\begin{array}{l}\text { Strategic planning can make your } \\
\text { institution to be among the best in the } \\
\text { vorld. }\end{array}$ & 221 & 53 & 21 & 295 & 2.68 & Agree \\
\hline 4. & $\begin{array}{l}\text { Your institution has a well known strategic } \\
\text { planning unit. }\end{array}$ & 159 & 104 & 32 & 295 & 2.43 & Disagree \\
\hline 5. & $\begin{array}{l}\text { The strategic planning Unit of your } \\
\text { institution is rich humanly, materially and } \\
\text { financially. }\end{array}$ & 117 & 73 & 105 & 295 & 2.04 & Disagree \\
\hline 6. & $\begin{array}{l}\text { Your institution has an active strategic } \\
\text { planning unit that designs strategic plans. }\end{array}$ & 130 & 100 & 65 & 295 & 2.22 & Disagree \\
\hline
\end{tabular}

Note $\mathrm{X}=$ Mean; Cut-off point $=2.50$.

Source: Field survey (2018).

Table 2 shows that there is no availability of popular strategic planning in most tertiary institutions in Kano state.

Table-3. Priorities of strategic planning in tertiary institutions in Kano State.

\begin{tabular}{c|l|c|c|c|c|c|c}
\hline $\mathbf{S} / \mathbf{N}$ & Items & $\mathbf{A}$ & $\mathbf{U}$ & Total & $\mathbf{X}$ & $\mathbf{R e m a r k}$ \\
\hline 1. & $\begin{array}{l}\text { Strategic plan in your institution gives } \\
\text { priorities to post-secondary education needs. }\end{array}$ & 199 & 66 & 30 & 195 & 2.57 & Agree \\
\hline 2. & $\begin{array}{l}\text { Priority was given to research, knowledge } \\
\text { transfer and international outlooks. }\end{array}$ & 144 & 111 & 40 & 195 & 2.35 & Disagree \\
\hline 3. & $\begin{array}{l}\text { Strategic plan in your institution gives } \\
\text { priorities to man-power need of the society. }\end{array}$ & 146 & 116 & 33 & 295 & 2.38 & Disagree \\
\hline 4. & $\begin{array}{l}\text { One of the goals of your institution's } \\
\text { strategic plan is enrolling many } \\
\text { international students to enhance } \\
\text { globalization. }\end{array}$ & 101 & 94 & 295 & 2.02 & Disagree \\
\hline 5. & $\begin{array}{l}\text { Strategic plan of your institution gives } \\
\text { priorities to vocational and entrepreneurial } \\
\text { skill acquisition of the students. }\end{array}$ & 154 & 96 & 45 & 295 & 2.37 & Disagree \\
\hline 6. & $\begin{array}{l}\text { Strategic planning of your institution } \\
\text { emphasis on modalities for financial } \\
\text { management and accountability. }\end{array}$ & 117 & 73 & 105 & 295 & 2.04 \\
\hline
\end{tabular}


Table 3 shows that the priorities of tertiary institutions strategic plans were not giving to important goals which could promote their productivity and their competitive advantage in the world ranking.

1.8. Results of Hypotheses Tested

Chi-square is used to test the hypothesis at 0.05 levels of significance as follows:

Table-4 Difference in the availability of strategic plan in the tertiary institutions

\begin{tabular}{|c|c|c|c|c|c|c|c|c|c|}
\hline $\begin{array}{c}\text { Tertiary } \\
\text { institutions }\end{array}$ & $\mathbf{A}$ & $\mathbf{U}$ & D & Total & $\begin{array}{c}\text { Cal.- } \\
\text { value }\end{array}$ & DF & $\mathbf{L S}$ & $\begin{array}{c}\text { Crit. } \\
\text { value }\end{array}$ & Decision \\
\hline Universities & $\begin{array}{c}362 \\
(339.96) \\
\end{array}$ & $\begin{array}{c}130 \\
(129.68) \\
\end{array}$ & $\begin{array}{c}81 \\
(103.35) \\
\end{array}$ & 573 & & & & & \\
\hline $\begin{array}{c}\text { Colleges of } \\
\text { education }\end{array}$ & $\begin{array}{c}372 \\
(355.98) \\
\end{array}$ & $\begin{array}{c}151 \\
(135.79)\end{array}$ & $\begin{array}{c}77 \\
(108.22)\end{array}$ & 600 & 50.62 & 4 & 0.05 & 9.488 & $\mathrm{HS}$ \\
\hline Polytechnics & $\begin{array}{c}312 \\
(350.05) \\
\end{array}$ & $\begin{array}{c}118 \\
(133.53) \\
\end{array}$ & $\begin{array}{c}160 \\
(106.42)\end{array}$ & 590 & & & & & \\
\hline Total & 1046 & 399 & 318 & 1763 & & & & & \\
\hline
\end{tabular}

Note: Expected frequencies are in brackets; HS: highly significant.

Source: Field survey (2018).

The Table 4 shows that the chi-square value is (50.62) which exceeded the critical value, degree of Freedom (4) and level of significant 0.05 is 9.488; this signifies rejecting the null hypothesis.

That is, there is significant difference on the status of strategic planning in tertiary institutions.

Table-5. Difference in the priorities of strategic plan in tertiary institutions in Kano State.

\begin{tabular}{c|c|c|c|c|c|c|c|c|c}
\hline $\begin{array}{c}\text { Tertiary } \\
\text { institutions }\end{array}$ & $\mathbf{A}$ & $\mathbf{U}$ & $\mathbf{D}$ & Total & Cal.-value & DF & LS & Crit. value & Decision \\
\hline Universities & $\begin{array}{c}339 \\
(297.50)\end{array}$ & $\begin{array}{c}148 \\
(180.22)\end{array}$ & $\begin{array}{c}77 \\
(86.28)\end{array}$ & 564 & & & & \\
\hline $\begin{array}{c}\text { Colleges of } \\
\text { education }\end{array}$ & $\begin{array}{c}352 \\
(317.01)\end{array}$ & $\begin{array}{c}130 \\
(192.05)\end{array}$ & $\begin{array}{c}119 \\
(91.94)\end{array}$ & 601 & 112.7 & 4 & 0.05 & 9.488 & HS \\
\hline Polytechnics & 240 & $\begin{array}{c}286 \\
(316.49)\end{array}$ & $\begin{array}{c}74 \\
(91.78)\end{array}$ & 600 & & & & & \\
\hline Total & 931 & 564 & 270 & 1765 & & & & & \\
\hline
\end{tabular}

Note: Expected frequencies are in brackets; HS: highly significant.

Source: Field survey (2018)

The table shows that the chi-square calculated value is 112.7. Since this is greater than the critical value of 9.488 at degree of Freedom 4 we reject $\mathrm{H}_{\mathrm{O}}$ at the 0.05 level of significance. We concluded that there is significant difference in the availability of Strategic Plans in Tertiary institutions in Kano State.

\section{Summary of Major Findings}

The following are the major findings obtain from the data analysis.

1. Majority of tertiary institution in Kano State do not have strategic plan which are popular among their staff let alone the students.

2. Strategic plans of tertiary institutions in Kano state do not give priorities to strategic goals that are capable of making them productive and promote them in the world rankings.

3. There is a high significant difference in the availability of strategic plans of tertiary institutions in Kano State.

4. Similarly, there is a high significant difference in the priorities given to strategic goals of strategic plans of tertiary institutions in Kano State.

\section{Discussion of Findings}

Majority of tertiary institutions in Kano State do not have a strategic plan which is popular among their employees. This is so terrible to the extent that the word "strategic planning" sounds so strange to many academic staffs that have been described earlier by Kariuki et al. (2016) as the foot soldiers of strategic implementation. Other academic staff who claimed updated confessed they have never seen the strategic plan of their institutions. This finding contradict (Kazadi, 2016) whose findings showed that $70 \%$ of non-education organizations surveyed have concrete plans and no significant relationship between the intensity of strategic planning and the number of staff.

Strategic goals of tertiary institutions in Kano state were of low standards as priorities in the plans were not given to important goals which could have promoted the institutions in the world ranking. For instance, Priority was not given to enrolling many international students using multiple strategies such as scholarship strategy. They seem to have forgotten what (Owolabi \& Makinde, 2012) says that Universities can benefit 
from strategic planning on the long run and the students enrolled are the ones to project the image of the institutions. Thus; the finding agreed with that of James and Ebuara (2015) who discovers a significant relationship between strategic plans and students' level of enrolment. Also, timely graduation of students was not prioritized. Priorities should be given to Research and citations, international outlook and awards, innovation and community engagement as well as discipline atmosphere for teaching and learning and Alumni Relation. All these are the primary roles of a world class University (Ayo et al., 2014). Similarly strategic goals' attention should be drawn to effective financial sourcing, management and accountability. Owolabi and Makinde (2012) explain in this regard that effective planning can provide universities with enough research grants. Simply put, through effective strategic planning, government and private industries which often benefits from the research findings, scientific discoveries and technological innovations may give the institution enough research grants capable of developing such Universities further.

McIlquham-Schmidt (2010) opines that effective planning and implementation has positive contribution to the financial performance of organizations. In this relation (Aremu, 2010) laments that some Nigerian business organizations are without formal plans and where there are formal plans, organizations operate without adhering to them. In as much as this is lacking, the findings of this study corroborates that of Toby (2010) who says that financial management and accountability of school administrators denote the extent to which these school heads assumes responsibility or answerable for what expenditure goes on in the school system. This controversy is in consonance with the research findings of Achimugu (2012) who observes that many secondary schools administrators run into serious problem because they often attempt to introduce innovations and programmes without first considering the cost and sources of funds.

There is a high significant difference in the availability of strategic plans of tertiary institutions in Kano State. That is, some institutions do not have strategic planning unit let alone strategic plan, some have substandard strategic plan which could not get the work done while the last group have poorly implemented strategic plan due to lack of popularity among their staff and students. This finding corroborates with that of Aremu (2010) who discovers that strategy is needed to focus effort and promote coordination of activities. Without strategy an organization becomes bunch of individuals, hence strategy is required to ensure collective actions and concentration of efforts towards achieving organizational plans and objective. In this relation Dauda, Akingbade, and Akinlabi (2010) conclude that strategic management practices enhance both organizational profitability and company market share and therefore suggest that strategic planning concepts should be adopted.

Similarly, there is a significant difference in the priorities given to strategic goals in strategic plans of tertiary institutions in Kano State. Since the priorities of the available strategic plans differ, the achievements in term of productivity and competitive advantages differ also. That is, the better the priorities the greater the achievements. This is in consonance with James and Ebuara (2015) who opined that the higher the strategic plan the more effective and successful is the implementation of academic programmes. Supporting this assertion, McIlquham-Schmidt (2010) posits that without a clearly defined strategy, a business will have no sustainable basis for creating and maintaining a competitive advantage in the industry where it operates. That is, without a clearly defined strategic planning in tertiary institutions in Kano State, it becomes impossible for them to compete favorably with their counterparts within and outside the country.

\section{Conclusions}

Based on the findings of this study, it is hereby concludes that lack of popular strategic planning in tertiary institutions in Kano State is responsible for their backwardness in term of institutional ranking in Africa and in the world at large. Also priority was not given to important goals that could have made the institutions productive and compete favorably with their international counterparts. The nature of strategic planning in tertiary institutions in Kano State differs. Hence, the need to get the institutions to the top varies. Finally, the priority given to strategic goals of tertiary institutions in Kano State are not the same across the institutional types.

\section{Recommendations}

In planning for sustainable quality of Nigerian education, the present educational strength, weaknesses, opportunities and threats needed to be adequately considered and put into considerations. Thus, the role of inspectors and supervisors of schools towards quality assurance should not be under-estimated. Patriotic Nigerian scholars with moral integrity and hardworking who knows the implication of covering lapses in educational system should be appointed as supervisors and inspector of schools. It is hereby recommended among others that:

1. The government should make strategic planning a must for all tertiary institutions in Kano State. This will help to improve their productivities and competitive advantages.

2. All tertiary institution in Kano State without strategic planning unit should formulate the unit and make it functional in terms of implementation, evaluation and feedback.

3. Strategic planning unit of the institutions should make the plan available to all staff and organized a seminar where the strategic goals and the strategies would be explained. 
4. Strategic plans of all institutions should be restructured to reflect strategic goals which are capable of ensuring productivity and promote their competitive advantages.

5. Delegation of duties and responsibilities should be done among the staff in such a way that everyone in the institution feel recognize and directly involve in one strategic goal or the other for effective implementation.

It is hereby believes that if all recommendations of this study is implemented accordingly tertiary institutions in Kano State will soon find themselves among the world best in term of rankings.

\section{References}

Achimugu, L. (2012). The agonies of Nigerian teachers (2nd ed.). Ibadan: Heinemann.

Aremu, M. A. (2010). Enhancing organizational performance through strategic management: Conceptual and theoretical approach.Retrieved from www.stratplanning/performance. [Accessed October 20, 2011].

Ayo, C., Daramola, O., Omonhinmi, C., Okodua, H., Iweala, E., \& Ibietan, O. (2014). Introducing the covenant university strategic plan (2014-2019), Ad hoc Commitee on Strategic Plan.

Chimuka, R. (2016). Effects of the strategic planning on pupils' academic performance in selected secondary schools of Lindazi District, Zambia. Master Dissertation, Zimbabwe Open University.

Dauda, Y. A., Akingbade, W. A., \& Akinlabi, H. B. (2010). Strategic management practice and corporate performance of selected small business enterprises in Lagos Metropolis. International Journal of Business and Management, 5(11), 97-105.

Federal Republic of Nigeria. (2013). National policy on education. Lagos NERDC Press.

Gawie, S., \& Masese, M. (2016). Strategic planning as a management tool for school principals in rural schools in the motheo district. International Journal of Educational Sciences, 13(3), 342-348.

James, O., \& Ebuara, V. O. (2015). Strategic plan and implementation of academic programmes in unity schools in SouthSouth, Nigeria. International Journal of Education and Research, 3(8), 14-22.

Kariuki, P. G., Maiyo, J., \& Ndiku, J. M. (2016). Relationship between strategic planning and performance of public secondary schools in Kangundo Sub-County, Machakos County, Kenya. IOSR Journal of Research \& Method in Education, 6(6), 99-105.

Kazadi, M. H., S. (2016). The effect of strategic planning on organization performance in industrial estate companies of Gachsaran 2014-2015year. International Journal of Humanities and Cultural Studies, 1(1), 1098-1108.

Kim, K. (2013). A case study concerning the strategic plan: v2020 of Chosun University of science. Journal of Business and Management, 1(4), 43-57.

McIlquham-Schmidt, A. (2010). Appraising the empirical evidence of the relationship between strategic planning \& corporate performance. Retrieved from www.hha.dk/man/cmsdocs/WP/2010/wp2010_03.pdf. [Accessed, September 15, 2011].

Ololube, N. P. (2013). Educational management, planning and supervision: Models for effective implementation. Owerri, Nigeria: Spring Field Publishers.

Owolabi, S. A., \& Makinde, O. G. (2012). The effects of strategic planning on corporate performance in university education: A study of Babcock University. Kuwait Chapter of Arabian Journal of Business and Management Revierw, 33(853), 1-18.

Research Advisors. (2006). The table of sample size. Retrieved from http://research-advisors.com/tools/SampleSize.htm.

Toby, C. (2010). Responsibility, authority and accountability of the school principal. The Nigerian Principal, 3(1), 87-94.

UniJos. (2015). The strategic planning manual of the university of Jos-2015. 